\title{
Surface depressions (Lacunas) on Bering Glacier, Alaska: a product of downwasting through differential ablation
}

\section{P. J. Fleisher}

Earth Sciences, SUNY-Oneonta, Oneonta, NY 13820, USA

Received: 1 March 2014 - Accepted: 24 March 2014 - Published: 12 May 2014

Correspondence to: P. J. Fleisher (fleishpj@oneonta.edu)

Published by Copernicus Publications on behalf of the European Geosciences Union.

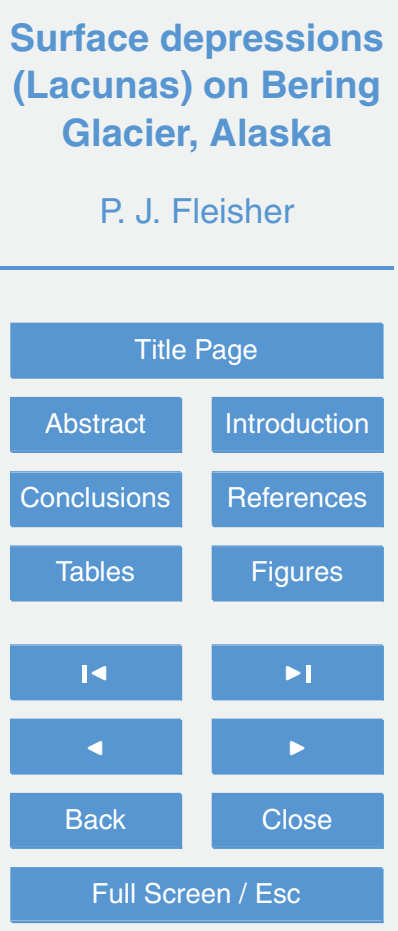

Printer-friendly Version

Interactive Discussion 


\section{Abstract}

Bering Glacier lacunas are steep-sided, flat-floored hollows ranging in size from 40 to $60 \mathrm{~m}$ wide, 80 to $120 \mathrm{~m}$ long, and 35 to $50 \mathrm{~m}$ in deep. They are confined within a band of clean ice ( $1.5 \mathrm{~km}$ wide, $5 \mathrm{~km}$ long) paralleling the eastern margin of the Bering piedmont

5 lobe. The 1993-1995 surge displaced the lacuna band several kilometers onto the foreland. Specifically significant is the formation of a new band of lacunas 5-6years later in the same location occupied by the displaced band prior to the surge.

Conditions essential to lacuna formation were initiated during the surge as overriding ice was thrust into position across the trend of a subglacial trough, leading to stagnation of ice within the trough. Stagnation combined with saturation at depth altered ice texture and density. Exposure of this ice through normal ablation led to areas of differential ablation and the formation of lacunas.

\section{Introduction}

The term "lacuna" seldom appears in the literature. Sturm (1987) suggests lacunas 15 may be associated with glaciers that surge, which would apply to the Bering where an anomalous band of more than one hundred lacunas appears on a segment of debris-free ice confined between folded debris bands near the eastern terminus of the piedmont lobe /. Although similar in size and shape to sink-holes that develop within debris-covered, stagnant-ice commonly referred to a "glacier karst", Bering Glacier lacunas form within clean ice and are not associated with any collapse features typical of glacier karst (Clayton, 1964). They are steep-walled, bowl-shaped cavities that lack the vertical conduit drainage typical of moulin. Instead they have gently sloping floors through which melt water seeps downward via fractures.

Of specific significance here is that after being displaced several kilometers by 25 a surge event, the lacuna band forms anew within 5-6 years in exactly the same origi-
Surface depressions (Lacunas) on Bering Glacier, Alaska

P. J. Fleisher

Title Page

Abstract Introduction

Conclusions References

Tables Figures

14 DI

4

Back

Close

Full Screen / Esc

Printer-friendly Version

Interactive Discussion 
nal location as the previously existing displaced band. During this interval, downwasting removed $55 \mathrm{~m}$ (182 feet) of surge-thickened ice.

The purpose of this paper is to explain the emergence of newly formed lacunas and to propose conditions favorable for their formation.

\section{Lacuna band location and description}

The eastern margin of the Bering piedmont lobe contains multiple debris bands tightly folded and kinked by past surge events (Post, 1972). Between folds, and in conspicuous contrast to the glacier surface elsewhere, is a linear band of lacunas $(1.5 \mathrm{~km}$ wide and $5 \mathrm{~km}$ long). The lacunas occupy ice that is entirely free of debris, unlike similar 10 depressions found within the heavily mantled, massive medial moraine between the Steller and Bering lobes (Fig. 1). The lacuna band is prominent and conspicuous on the up-glacier side of Arrowhead Island between Vitus Lake and Tsiu Lake.

A review of US Geological Survey aerial photos, early photos by Bradford Washburn, and subsequent photos by Austin Post indicate the persistence of a lacunas band dat15 ing back to the surge of 1938-1940. When fully developed the band consists of approximately 150 lacunas, each large enough to be prominent on aerial photos (Fig. 2). Although the general distribution appears random, groups of 10-15 are locally aligned along a SW-NE trend, whereas others favor a subtle NW-SE trend. The entire band encompasses an area of 6 to $7 \mathrm{~km}^{2}$. Nowhere else on the entire $100 \mathrm{~km}^{2}$ of the active 20 Bering piedmont lobe are lacunas present.

Many lacunas appear circular, although the majority are slightly oblate with the long axis oriented in the up-glacier direction and parallel to a prominent fracture pattern. Although they vary significantly in size and relief, they are commonly 40 to $60 \mathrm{~m}$ wide, 80 to $120 \mathrm{~m}$ long, and 35 to $50 \mathrm{~m}$ deep. Lacuna walls are steeply inclined between $20^{\circ}$ and $40^{\circ}$ descending from a broad crowning rim to a gently concave floor (Fig. 3).

Englacial structures are clearly represented 3-dimentionally within lacuna walls, including normal foliation, surge-related thrust planes, fractures, and sparse debris filled

Surface depressions (Lacunas) on Bering Glacier, Alaska

P. J. Fleisher

Title Page

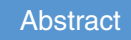

Introduction

Conclusions

References

Tables

Figures

14

- I

4

Back

Close

Full Screen / Esc

Printer-friendly Version

Interactive Discussion 
hydrofractures (Fleisher et al., 2010). Foliation strikes NE-SW and dips moderately up-glacier, averaging 41. Thrust planes, conspicuous due to traces of fine debris distributed on the surface by meltwater, are semi-parallel to foliation and dip 24 to 41 up-glacier. Fractures that appear to be remnant crevasses strike NW-SE and also dip 5 steeply (68) (Fig. 4). Debris-filled hydrofractures strike to the NE and SE and dip between 37 and 47 up-glacier. Some occupy foliation planes. All structures are laterally continuous without interruption within each lacuna and throughout the entire lacuna band. Thus indicating collapse is not involved in the formation of lacunas.

\section{Glacier karst distinction}

10 As described by Clayton (1964), the term "glacier karst" implies a configuration of glacier features formed on stagnant, debris covered ice that resemble those on limestone karst. Most prominent are funnel-shaped sink-holes formed by the collapse of ice cave roofs, tunnels, sinking springs and blind valleys as found on the Martin River Glacier, Alaska. Their formation requires localized ablation provided by a debris cover 15 of variable thickness followed by backwasting and slope retreat (Embleton and King, 1968). Clayton considers moulin as part of glacier karst, but acknowledges the larger variety of vertical shafts into which large meltwater streams plunge are most common on active ice.

According to Clayton, sink-holes within glacier karst are steep-walled, conical depressions that commonly contain ponds at a common water level which is taken to represent the position of the local water table, implying saturation at depth. No definitive mechanism other than collapse has been offered to explain their origin. However, their non-angular, symmetrical surface expression and lack of associated tilted ice blocks due to subsidence suggest otherwise. Similarly, englacial structural continuity within sidence. Benn and Evans (1998) attribute sink-hole enlargement to backwasting of ice slopes too steep to support debris cover, but do not offer an initiating mechanism for

Surface depressions

(Lacunas) on Bering Glacier, Alaska

P. J. Fleisher

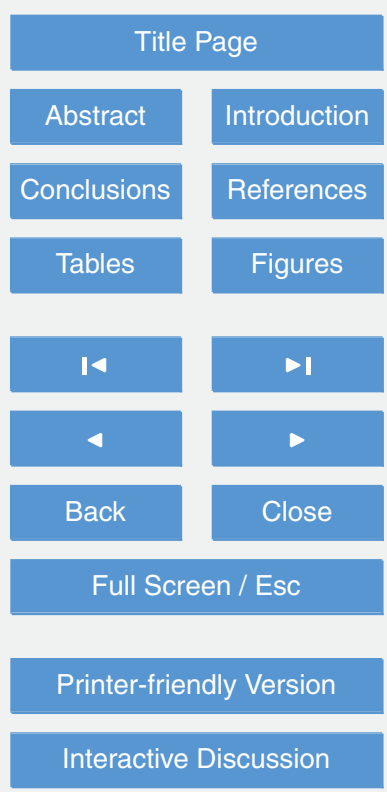


their formation. An area of glacier karst is well developed on the debris covered distal end of the broad medial moraine separating the actively moving Bering and Steller piedmont lobes. While the lacunas at Bering Glacier are similar in size and shape to sink-holes, and share an affinity for passive to stagnant ice, they are most conspicuous 5 within a band of debris-free ice on the opposite side of the piedmont lobe, although some may indeed also appear in the area of glacier karst.

\section{Lacuna band saturation}

As surging advance pressed the ice front onto all eastern sector islands and into all icecontact lakes in 1993, the narrows at the western tip of Bentwood Island was closed 10 and Tsiu and Tsivat Lakes rose $14 \mathrm{~m}$ thus forcing the reoccupation of a pre-surge outlet (Abandoned River). An upwelling fountain of turbid water that had been active for several years at the Lake Vitus ice front adjacent to Arrowhead Island during the surge was conspicuous as plumes of silty water entered the clear, slightly brackish water of Lake Vitus. Discharge here progressively increased after the surge ended (1995) that clearly 15 established an enlarging englacial hydrologic connection between Tsiu Lakes and Vitus Lake, which is interpreted to suggest increased saturation beneath the lacuna band (Fleisher et al., 2013). Saturation persisted at depth here for several years as the ice front slowly retreated from the surge limit and downwasting progressed. During the interval that followed, water from the adjacent elevated Tsiu Lake continued to gain internal access to the ice beneath the lacuna band, until in 2006 turbid water began to appear within some lacunas indicating the filling of englacial cavities (Crossen et al., 2012) and a rising water table. During the summer of 2006 a surface channel formed from Tsiu Lake to a conduit opening on the glacier and supraglaciel drainage began (personal communication Chris Noyes, BLM, Anchorage, Alaska; Fleisher et al., 2006).

25 The connecting englacial drainage system was gradually enlarged sufficiently to cause the beginning of a week-long breakout into Vitus Lake (Crossen, 2012) as Tsiu and Tsivat Lakes were lowered to pre-surge elevations. The breakout lowered the surface

Surface depressions (Lacunas) on Bering Glacier, Alaska

P. J. Fleisher

Title Page

Abstract Introduction

Conclusions References

Tables Figures

14 DI

4

Back

Close

Full Screen / Esc

Printer-friendly Version

Interactive Discussion 
of Tsiu Lake sufficiently to expose ice front tunnel openings through which turbid lake water had gained access to englacial passageways beneath the lacuna band. Eventually, in mid summer 2007, the englacial conduits were enlarged sufficiently to cause ceiling collapse resulting in the formation of an open channel outlet between Tsiu Lake 5 and Lake Vitus. The length of time during which the lacunas remained flooded, and presumably the water table within the trough was elevated, is unknown.

\section{Surge deformation related to lacuna band location}

Surface deformation of the piedmont lobe during the 1993-1995 surge, as well as earlier surges, as observed in over-flights and on US Geological Survey aerial photos 10 (Post, 1972), formed heavily crevassed domes separated by crevasse-free troughs. The domes are assumed to coincide with ice movement above subglacial topographic highs, whereas sagging ice and troughs form above areas of subglacial lows (Fig. 5).

\subsection{Surface expression of subglacial trough}

A particularly conspicuous trough formed at the glacier surface where the Tsiu Lake basin is projected to extend beneath the ice. Here, well-developed, large ephemeral linear ponds formed within the trough, thus emphasizing its size, extent and orientation due to subsidence above a subglacial low. In contrast, heavy crevassed ice moving over the adjacent Peat Falls and Arrowhead Islands served to further emphasize the crevasse-free ice sagging into the trough (Fig. 5).

20 Surging advance was accompanied by the eastward thrusting of multiple, gently inclined wedges of ice stacked one on another. By July 1994, mid way through the surge after the majority of ice displacement had occurred, the ice had thickened between 50$70 \mathrm{~m}$ (150-210 feet) at the eastern margin (Fleisher et al., 2010). These values proved to be slightly too high, as determined by initial post-surge ablation estimates that would have removed an estimated $45 \mathrm{~m}$ by 1998 and a total of $65 \mathrm{~m}$ by 2000 when all of the

Surface depressions (Lacunas) on Bering Glacier, Alaska

P. J. Fleisher

Title Page

Abstract Introduction

Conclusions References

Tables Figures

14 $D I$

4

Back

Close

Full Screen / Esc

Printer-friendly Version

Interactive Discussion 
surge related thickening had been removed by downwating. Pre- and post-surge ice flow data indicate that ice movement toward the margin between surges within this part of the piedmont lobe is normally very slow, less than the average retreat rate of 170 myear $^{-1}$ (Muller and Fleisher, 1995). However, during the surge the ice here ad5 vance 3 to $7 \mathrm{mday}^{-1}$ in a direction primarily across the trend of the trough (Fig. 5) (Fleisher et al., 1995, 2010). Thrusting ice movement across the trend of the trough would effectively separate overriding ice from ice held deep within the trough.

The azimuth of the trough suggests a continuation of the Tsiu Lake basin beneath the glacier, where it shifts from a westward trend at the to the southwest as it skirts the up10 glacier side of Arrowhead Island. Tsiu Lake bathymetric data indicate a minimum water depth of 40 to $43 \mathrm{~m}$ (130 to 140 feet) at the ice front prior to the surge (Fleisher et al., 1993, 2003). Adding the average relief of adjacent Peat Falls Island (30 m determined from field survey data) to the depth of Tsiu Lake, places the local relief of the trough at approximately $70 \mathrm{~m}$. Ice penetrating radar data (Trabant and Molina, 1992) indicate

15 an anomalous ice thickness along this trend at $-161 \mathrm{~m}$ relative to sea level. Lesser ice thickness beneath adjacent parts of the glacier confirms the continuation of Tsiu Lake basin beneath the glacier along a trend toward Lake Vitus. The southwest orientation of the trough persists and extends to the ice front at Vitus Lake where the water depth is $50 \mathrm{~m}$ (Molnia and Post, 1995), which matches the water depth at the ice front of Tsiu 20 Lake, thus establishing the trough as a continuous subglacial feature between Lake Vitus and Tsiu Lake.

\subsection{Lacuna band coincides with trough location}

It is particularly significant to note that after the lacuna band was displaced $2 \mathrm{~km}$ onto the foreland by the 1993-1995 surge (Fleisher, et. al, 2010), new lacunas began to 25 appear within 5-6years in a location that coincides with the original position of the lacuna band prior to surge displacement. Furthermore, the location of newly formed lacunas coincides with the position of the trough formed above the subglacial low, a fact that links lacuna formation to the ice within the trough.

Surface depressions

(Lacunas) on Bering Glacier, Alaska

P. J. Fleisher

Title Page

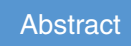

Introduction

Conclusions References

Tables Figures

14

$D I$

4

Back

Close

Full Screen / Esc

Printer-friendly Version

Interactive Discussion 
For all practical purposes ice held deep within the trough persisted in a passive to stagnant condition beneath overriding ice throughout the surge only to be exposed at the glacier surface years later by downwasting due to ablation (Fig. 6).

\section{Rates of ablation}

\section{$5 \quad 6.1$ Initial post-surge accelerated ablation}

When the surge ended in September 1995, much of the glacier surface was intensely broke by chaotic crevasses. Debris bands that were conspicuous prior to the surge were completely eradicated as virtually all debris fell into crevasses. As would be anticipated, increased surface area of the broken ice surface led to accelerated melting, so that by 1997-1998 most of the heavily crevassed ice was lost to ablation. Annual field observations indicate the minimum amount of time required for the debris within the crevasses to appear again at the surface as re-formed debris bands was 2-3 years (Mase et al., 1997). This indicates initial post-surge lowering of the broken glacier surface was equal to the depth at which most debris would lodge within open crevasses, which is estimated to be $35 \mathrm{~m}$ (Hooke, 2005), thus establishing an initial post-surge minimum ablation rate of approximately $12-18$ myear $^{-1}$.

\subsection{Normal rate of ablation}

After initial post-surge ablation removed the heavily crevassed ice and reduced the glacier surface to a safe gradient, annual ice surface surveys were conducted at four different locations along the eastern sector between 1998 and 2006. The surveys started at the ice front and progressing $1 \mathrm{~km}$ up-glacier across clean ice. A plot of the 9 year survey record from a representative segment of the eastern sector (Fig. 7) indicates the clean ice surface was lowered at a normal rate of 10 myear $^{-1}$ (Fleisher et al., 2005, 2010). By 2000 the initial $35 \mathrm{~m}$, plus 2 years at 10 myear $^{-1}$ would have lowered the glacier surface a total of approximately $55 \mathrm{~m}$ (182 feet). At this time ice held deep within

\section{0}

Surface depressions

(Lacunas) on Bering

Glacier, Alaska

P. J. Fleisher

Title Page

Abstract

Introduction

Conclusions

References

Tables

Figures

14

DI

4

Back

$>$

Close

Full Screen / Esc

Printer-friendly Version

Interactive Discussion 
the trough would have been exposed at the surface. Photos taken in 2000 indicate that by this time an entirely new band of lacunas had fully formed.

Figure 7. Annual ice surface profiles 1998-2006 from Weeping Peat Island survey station indicate a general downwasting rate of 10 myear $^{-1}$ (from Fleisher et al., 2010)

\section{Discussion}

\subsection{Lacuna association with stagnant ice}

Pre- and post-surge ice flow data indicate that within this segment of the piedmont lobe movement is consistently very slow. However during the 1993-1995 surge, the ice front advanced 3-7 mday $^{-1}$ as it was thrust across the trend of a subglacial trough expressed by ice surface deformation (Fleisher et al., 2010). Deep within the overridden trough the ice would have persisted in a passive-to-stagnant condition. During the 5-6years following the surge downwasting lowered the glacier surface sufficiently to remove all of the surge-thickened ice and eventually exposed the ice held deep within the trough. The location of the Bering lacuna band that forms anew after each surge coincides exactly with the location and orientation of this subglacial trough. This association links the trough to the lacuna band and suggests the properties of the ice within the trough are important to lacuna development.

Features similar to lacunas form within a zone of glacier karst that characterizes the stagnant interlobate ice separating the Bering and Steller piedmont lobes. Larson (1977) in his investigation of stagnant ice associated with the wasting Burroughs Glacier, Alaska characterized the internal drainage of stagnant ice to be similar to that of a karst setting, pointing out that infiltrating meltwater is temporary stored in saturated zones prior to being discharging into moulin-like surface cavities and released to englacial drainageways. Therefore, it is suggested that the stagnant conditions of glacier karst and the stagnant ice trapped within the subglacial trough would be subject to similar hydrologic conditions, including saturation at depth, and that ablation at

Surface depressions (Lacunas) on Bering Glacier, Alaska

P. J. Fleisher

Title Page

Abstract Introduction

Conclusions References

Tables Figures

14 DI

4

Back

Close

Full Screen / Esc

Printer-friendly Version

Interactive Discussion 
the surface would produce similar depressions, such as sink-holes in one area and lacunas in the other. It is suggested that properties developed within saturated stagnant ice, eventually leads to the development of these similar features.

\subsection{Saturation of stagnant ice}

5 In the case for active ice, surface meltwater flows along fractures and within crevasses to depths where it either refreezes or encounters englacial conduits through which drainage may be rapid (Fountain and Walder, 1998). This has been noted at Bering Glacier where surface melting and infiltration keeps pace with an annual downwasting of 10 myear $^{-1}$. Although the Burroughs Glacier, Alaska has been in rapid retreat for

10 more than a century (Mickelson, 1971) and ice movement is generally retarded and active flow persists at depth (Taylor, 1962), which accounts for a local perched water above less permeable ice (Syverson and Mickelson, 2009), thus suggesting a lack of persistent saturation. In contrast, water movement within stagnant ice is sluggish, thus contributing to the potential for saturation. Indeed, standing water at a common elevation in glacier karst sink-holes suggests limited drainage and a water table below which saturation would exist, as suggested by Larson (1977) for regions of Burroughs Glacier. Within the stagnant ice of glacier karst there is the additional influence of surface meltwater storage within channels and open fractures as on the stagnant Burroughs (Larson, 1978), and a fluctuating water table that rises and falls seasonally, thereby subjecting the ice at depth to episodic saturation. As noted earlier, ice held deep within the subglacial trough would be retained in a passive to stagnant condition as surging ice was thrust across the trend of the trough. This ice would then be susceptible to conditions of saturation and eventually the development of lacunas.

Indeed, during each documented surge event at the Bering a similar episodic saturation takes place at depth beneath the lacuna band. As surging ice pressed onto the foreland the normal outlet drainage of Tsiu Lake was blocked causing the lake to rise $14 \mathrm{~m}$. At this elevated position turbid water gained access to lacuna band ice as indicated by the rising encroachment of these waters into lacunas and storage of water

Surface depressions

(Lacunas) on Bering Glacier, Alaska

P. J. Fleisher

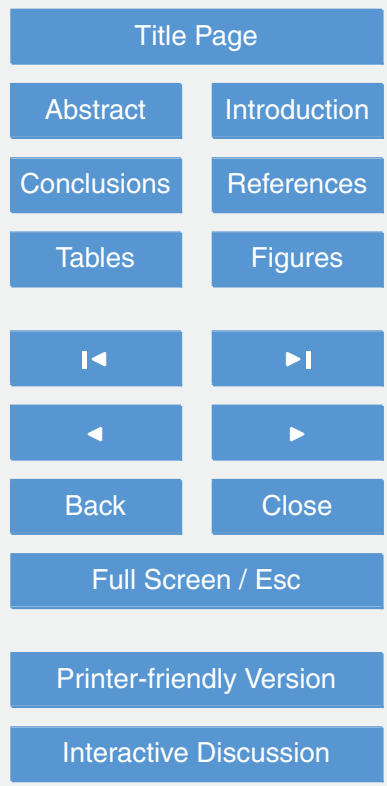


at depth (Crossen et al., 2012). This situation ended with the drainage of turbid water from lacunas after a breakout opened surface drainage into Lake Vitus and Tsiu Lake returned to its pre-surge level, thus causing the water table beneath the lacuna band to be lowered.

\section{7.3 Lacunas form in stagnant not active ice}

An additional factor for consideration in the development of lacunas is ice density. Lacunas and sink-hole are not found within actively flowing ice, a situation that may be explained by considering the components of active ice deformation. In defining the rate of active ice deformation, Nye's Flow Law assumes active ice is isotropic (Hooke, 2005) tion (Embleton and King, 1968). Unlike several other factors that define the physical properties of glacier ice, density is conventionally assigned a uniform value in quantitative calculations of active ice flow and intracryatlline deformation. Therefore, it is reasonable to assume that active ice flow maintains a relatively uniform density at depth 15 (Meier, 1972; Benn and Evans, 1998). Should flow within the glacier cease or become passive, as it may for a variety of reasons, the ice will stagnate. Consequently, infiltrating meltwater will eventually reach a temporary water table and saturate the ice at depth. In the absence of ongoing intracrystalline deformation, migration of water within a zone of saturation will result in the compromising of englacial texture (Raymond and 20 Harrison, 1975). Lacking established literature on the specific effects of saturation, one can only speculate on how the properties of stagnant ice would be altered. A reasonable modification would be the development of randomly distributed zones of slightly lower density. The logical outcome would eventually be expressed when normal downwasting exposes this ice at the glacier surface and the less dense ice would ablate at an accelerated rate, thereby resulting in differential ablation. With continued downwasting, such conditions would be expressed by the development of local depressions or surface cavities, such as ponded lacunas. The same may also take place within areas of glacier karst, thus forming some sink-holes. Darker pond water with a lower albedo

\section{3}

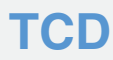

8, 2403-2424, 2014

Surface depressions

(Lacunas) on Bering Glacier, Alaska

P. J. Fleisher

Title Page

Abstract Introduction

Conclusions References

Tables Figures

14 - I

4

Back

Close

Full Screen / Esc

Printer-friendly Version

Interactive Discussion 
would absorb increased solar radiation leading to increased melting and lacuna growth (Jeffries et al., 2013). Furthermore, enlargement appears to be controlled by englacial structures, such as fractures inherited from old crevasses, foliation and healed thrust plans. The result would be asymmetric lacunas as noted in Fig. 2.

\section{Summary and conclusions}

After hundreds of lacunas, limited within a $7.5 \mathrm{~km}^{2}$ band of clean ice, are displaced several kilometers by the 1993-1995 surge, a new band formed 5-6years later in the same location as the previous band. The location and orientation of the new lacuna band coincides with a subglacial trough expressed during the surge as a linear trench at the glacier surface. The horizontal thrust mechanism involved in surge displacement forced ice across the trend of the trough. This process effectively trapped ice deep within the trough causing it to become passive and eventually stagnant. Stagnant conditions led to englacial saturation that compromised ice texture resulting in randomly distributed pockets of diminished density. After this ice is exposed at the glacier surface 15 through 5-6 years of normal ablation and downwasting, a new lacuna band began to form. This progression of events links lacuna formation to the ice within the trough and accounts for the appearance of a new lacuna band following each surge. Stagnation and saturation at depth are key components in the development of conditions leading to differential ablation and the lacuna forming process.

Acknowledgements. The results of field work cited in this investigation were collected by the Bering Research Group (BERG) spanning several summers. Key members of the BERG group are Palmer K. Bailey and Eric Natal, plus more than a dozen students from the State University of New York, College at Oneonta. Prominent among the students were Dan Nierenberg and Dave Mase. The author is also grateful for the cooperation and assistance by the Prince William 25 Science Center, Cordova, Alaska, namely Nancy Bird and Penny Oswalt.

Surface depressions (Lacunas) on Bering Glacier, Alaska

P. J. Fleisher

Title Page 


\section{References}

Benn, D. I. and Evans, D. J. A.: Glaciers and Glaciation, Arnold, London, 734 pp., 1998.

Clayton, L.: Karst topography on stagnant glaciers, J. Glaciol., 5, 107-112, 1964.

Crossen, K. J., Fleisher, P. J., and Bailey, P. K.: Glacial outburst flood: 15-year cycle of the icecontact Tsiu Lake, Bering Glacier, Alaska, vol. 44, Geological Society of America Abstracts with Programs, Denver, Colorado, USA, 186 pp., 2012.

Embleton, C. and King, C. A. M.: Glacial and Periglacial Geomorphology, St. Martin's Press, New York, 608 pp., 1968.

Fleisher, P. J., Gardner, J. A., and Franz, J. M.: Bathymetry and Sedimentary Environment in Proglacial Lakes at the Eastern Bering Piedmont Glacier of Alaska, J. Geol. Educ., 41, 267-274, 1993.

Fleisher, P. J., Muller, E. H., Cadwell, D. H., Rosenfeld, C. I., Bailey, P. K., Pelton, J. M., and Puglisi, M. A.: The surging advance of Bering Glacier, Alaska, A progress report, J. Glaciol., 41, 207-213, 1995.

15 Fleisher, P. J., Bailey, P. K., and Cadwell, D. H.: A decade of sedimentation in ice-contact, proglacial lakes, Bering Glacier, Alaska, J. Sediment. Geol., 60, 309-324, 2003.

Fleisher, P. J., Bailey, P. K., Natel, E. M., Miller, J. R., and Tracy, M. W.: Post-surge field measurements of ablation and retreat, Eastern sector, Bering Glacier, Alaska, Abstracts with Program, Geological Society of America, Salt Lake City, Utah, USA, 37, p. 423, 2005.

Fleisher, P. J., Bailey, P. K., and Natel, E. M.: Ice dam breakout at Bering Glacier, Alaska, Abstracts with Program, Geological Society of America, Philadelphia, Pennsylvania, USA, 38, p. 236, 2006.

Fleisher, P. J., Bailey, P. K., Muller, E. H., Cadwell, D. H., Natel, E. M., and Russell, A. J.: The 1993-95 Surge and Associated Outburst Floods, Bering Glacier, Alaska; in: Bering Glacier: Interdisciplinary Studies of Earth's Largest Temperate Surging Glacier, edited by: Shuchman, R. A., and Josberger, E. G., Geological Society of America, Special Paper, Boulder, Colorado, USA, 462, 193-216, 2010.

Fleisher, P. J., Bailey, P. K., Nierenberg, D. R., Mase, D., and Natel, E. S.: Imagery in the analysis of enigmatic differential ablation, Bering Glacier, Alaska, Abstracts with Program, Geological

Fountain, A. G. and Walder, J. S.: Water flow through glaciers, Rev. Geophys., 36, 299-328, 1998.

Surface depressions

(Lacunas) on Bering Glacier, Alaska

P. J. Fleisher

Title Page

Abstract

Introduction

Conclusions

References

Tables

Figures

14

$>1$

4

Back

$>$

Close

Printer-friendly Version

Interactive Discussion 
Hooke, R. B.: Principles of Glacier Mechanics, Prentice Hall, Upper Saddle River, NJ, 429 pp., 2005.

Jeffries, M. O., Overland, J. E., and Perovich, D. K.: The arctic shifts to a new normal, Physics Today, 66, 35-40, 2013.

5 Larson, G. J.: Internal drainage of stagnant ice: Burroughs Glacier, Southeast Alaska, Institute of Polar Studies Report No. 65 and Department of Geology and Mineralogy, The Ohio State University, Columbus, 33 pp., 1977.

Larson, G. J.: Meltwater Storage in a Temperate Glacier, Burroughs Glacier, Southeast Alaska; Institute of Polar Studies Report No. 66, Institute of Polar Studies, The Ohio State University,

10 Columbus, 56 pp., 1978.

Mase, D. F., Nierenber, D. R., Fleisher, P. J., Bailey, P. K., and Natel, E. M.: The enigmatic occurrence of glacial lacunas, Bering Glacier, Alaska, Abstracts with Program, Geological Society of America, Durham, New Hampshire, USA, 38, p. 423, 2007.

Meier, M. F.: Hydraulics and hydrology of glaciers, in: The role of snow and ice in hydrology, in: 15 Proceedings of the Banff Symposium, 1 September 1972, Unesco - WMO (World Meteorological Organization) - IAHS (International Association of the Hydrological Sciences, Banff, British Columbia, Canada, 353-370, 827 pp., 1972.

Mickelson, D. M.: Glacial Geology of the Burroughs Glacier Area, Southeastern Alaska, Institute of Polar Studies Report No. 40, Research Foundation and the Institute of Polar Studies, The

20 Ohio State University, Columbus, Ohio, USA, 149 pp., 1971.

Muller, E. H. and Fleisher, P. J.: Surge history and potential for renewed retreat, Bering Glacier, Alaska, Arctic Alpine Res., 27, 81-88, 1995.

Molina, B. F. and Post, A.: Holocene history of Bering Glacier, Alaska: a prelude to the 1993-95 surge, Phys. Geogr., 16, 87-117, 1995.

Post, A.: Periodic surge origin of folded medial moraines on Bering Piedmont Glacier, Alaska, J. Glaciol., 11, 219-226, 1972.

Raymond, C. F. and Harrison, W. D.: Some observations on the behavior of the liquid and gas phases in temperate glacier ice, J. Glaciol., 14, 213-233, 1975.

Sturm, M.: Observations and characteristics of potholes on surging glaciers, J. Geophys. Res., 92, 9015-9022, 1987.

Syverson, K. M. and Mickelson, D. M.: Origin and significance of lateral meltwater channels formed along a temperate glacier margin, Glacier Bay, Alaska, Boreas, 38, 132-145, 2009.

Surface depressions

(Lacunas) on Bering Glacier, Alaska

P. J. Fleisher

Title Page 
Taylor, L. D.: Ice Structures, Burroughs Glacier, Southeast Alaska, Institute of Polar Studies Report No. 3, Research Foundation and the Institute of Polar Studies, The Ohio State University, Columbus, Ohio, USA, 80 pp., 1962.

Trabant, D. C. and Molina, B. F.: Ice thickness measurements of Bering Glacier, Alaska and their relation to satellite and airborne SAR image patterns; EOS, Transactions of the American Geophysical Union, Washington, D.C., USA, 73, 1992.

Surface depressions (Lacunas) on Bering

Glacier, Alaska

P. J. Fleisher

Title Page

\section{Full Screen / Esc}



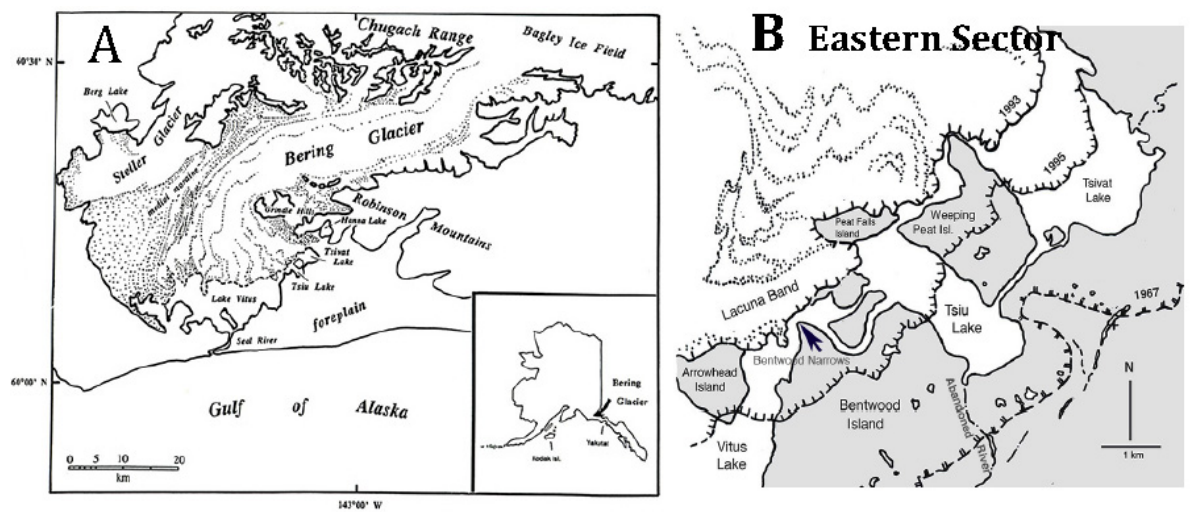

Fig. 1. Index map (A) and location of lacuna band relative to key eastern sector (B) physiographic features.
TCD

8, 2403-2424, 2014

Surface depressions (Lacunas) on Bering Glacier, Alaska

P. J. Fleisher

Title Page

\section{Full Screen / Esc}

Printer-friendly Version

Interactive Discussion 


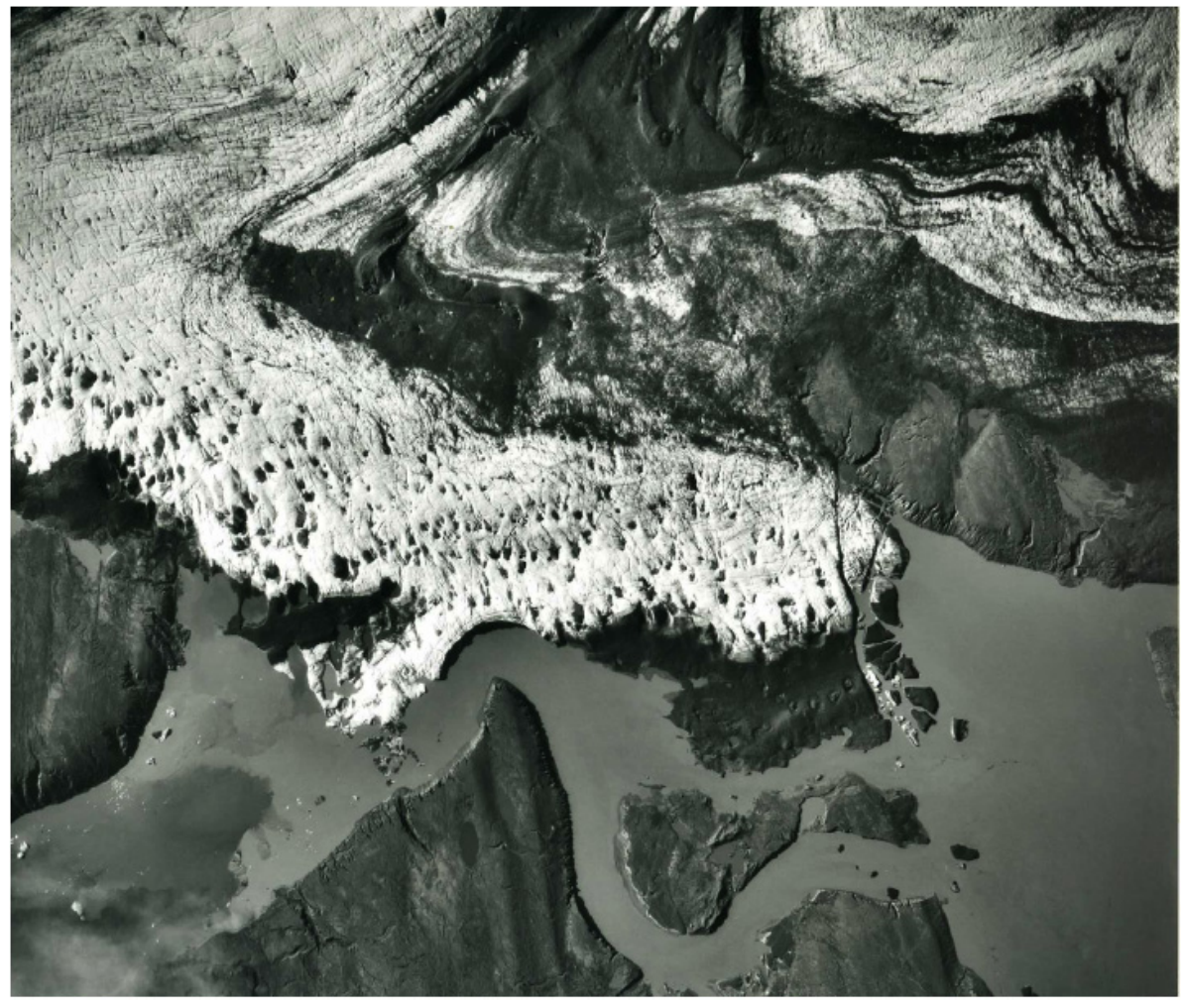

\section{TCD}

\section{8, 2403-2424, 2014}

Surface depressions (Lacunas) on Bering Glacier, Alaska

\section{P. J. Fleisher}

Title Page

Abstract Introduction

Conclusions References

Tables Figures

14

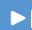

4

Close

\section{Full Screen / Esc}

Printer-friendly Version

Interactive Discussion 


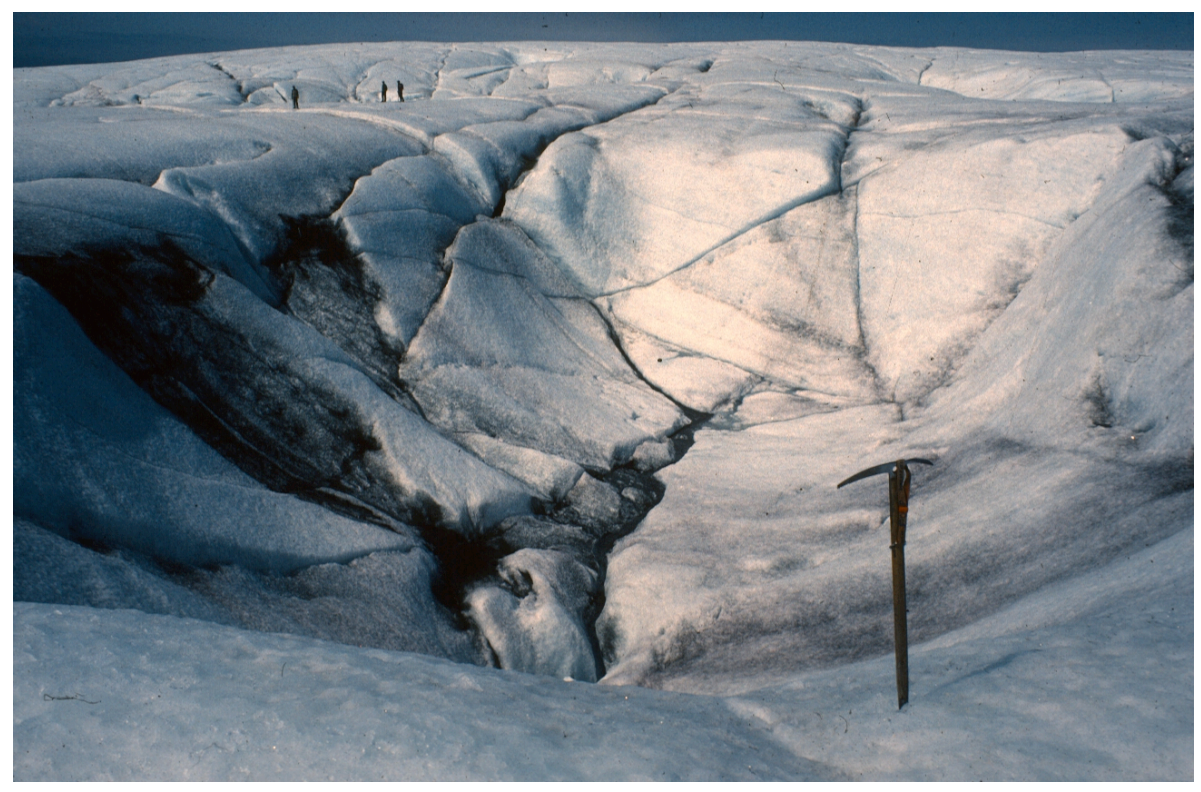

\section{TCD}

\section{8, 2403-2424, 2014}

Surface depressions (Lacunas) on Bering

Glacier, Alaska

\section{P. J. Fleisher}

Title Page

Fig. 3. Typical lacuna morphology. Foliation expressed in lacuna walls is not deformed by collapse. Scale implied by people on crown of far wall and ice axe in foreground. Note linear fracture on lacuna floor fracture through which surface melt drains. Photo by author, J-19-90.

\section{Close}

Full Screen / Esc

Printer-friendly Version

Interactive Discussion 


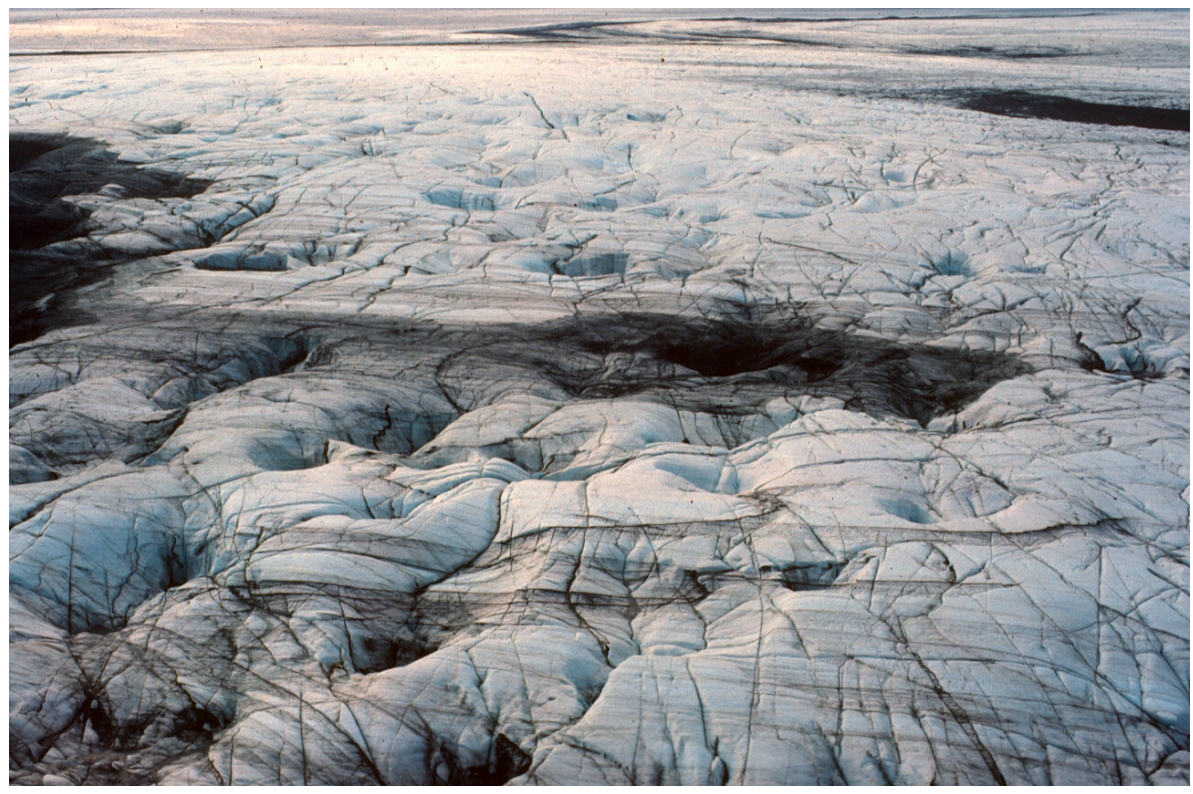

Fig. 4. Oblique view along trend of lacuna band (20 October 1993). Dark streaks passing through the lacunas are the product of fine debris ablating from pre-1993-1995 surge thrust planes, which are semi parallel to foliation. Photo by author, 10 October 1993.

\section{TCD}

$8,2403-2424,2014$

Surface depressions (Lacunas) on Bering

Glacier, Alaska

P. J. Fleisher

Title Page

Abstract

Introduction

Conclusions

References

Tables

Figures

$1<$

$D$

4

Back

Close

Printer-friendly Version

Interactive Discussion 


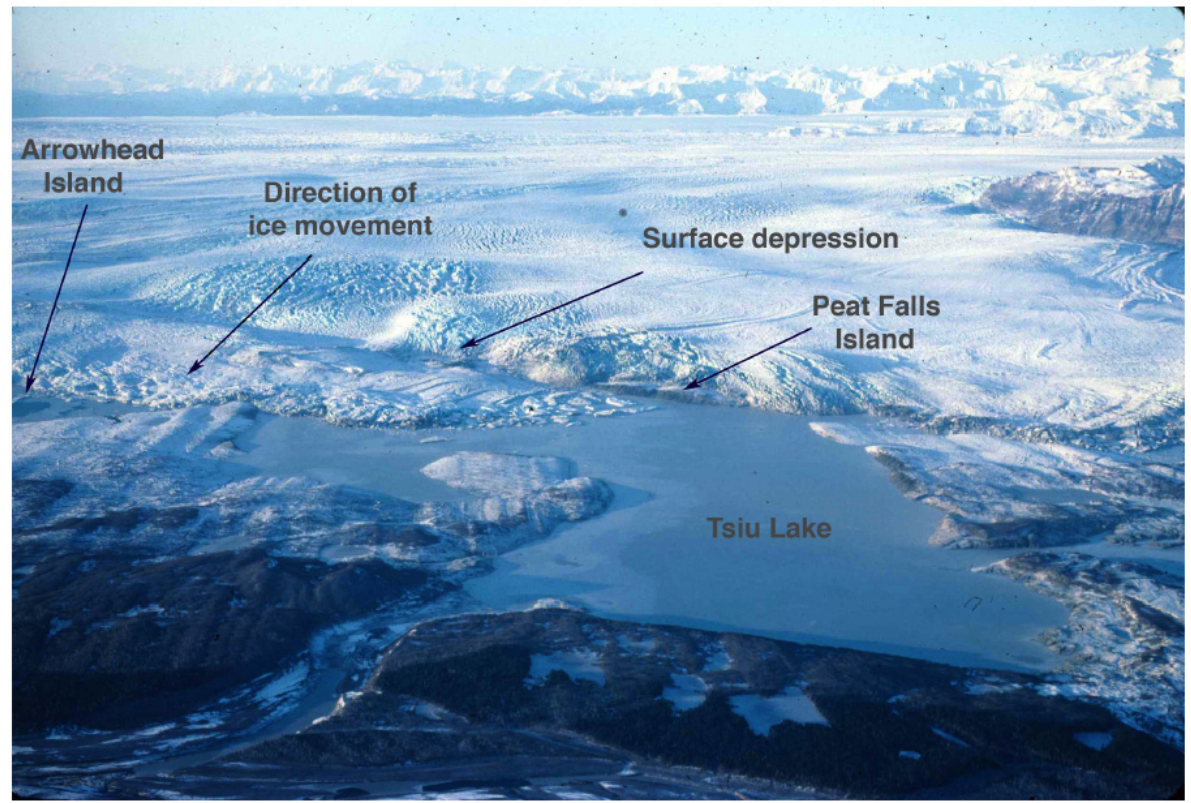

Surface depressions (Lacunas) on Bering Glacier, Alaska

\section{P. J. Fleisher}

\section{Title Page}

Abstract Introduction

Conclusions

References

Tables

Figures

14

4

Fig. 5. Subglacial relief expressed along the eastern Bering piedmont lobe during the surge. Heavily crevassed domes separated by depressions depict the relief of overridden subglacial terrain. The Tsiu Lake basin extends beneath the glacier as a subglacial trough above which a linear surface depression has formed. Arrow indicates ice movement direction across the trend of the subglacial trough. Photo by author (20 November 1993) 5 months after surge began. Photo by author, R-5-93.

$>$

\section{Close}




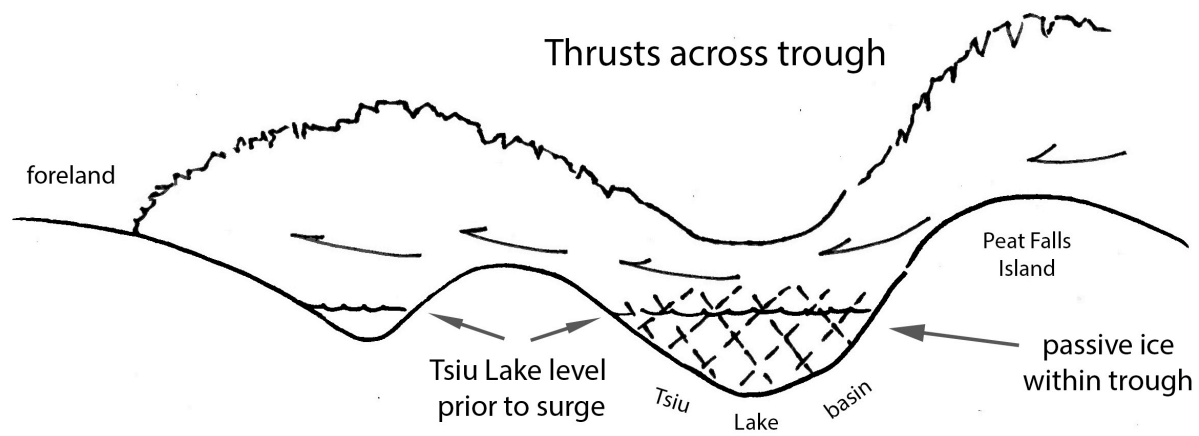

$\mathrm{VE}=10$

Fig. 6. Schematic diagram illustrating passive ice trapped within the subglacial trough during the surge.

\section{TCD}

$8,2403-2424,2014$

Surface depressions (Lacunas) on Bering

Glacier, Alaska

P. J. Fleisher

Title Page

Abstract

Introduction

Conclusions

References

Tables

Figures

14

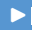

Back

Close

Full Screen / Esc

Printer-friendly Version

Interactive Discussion 


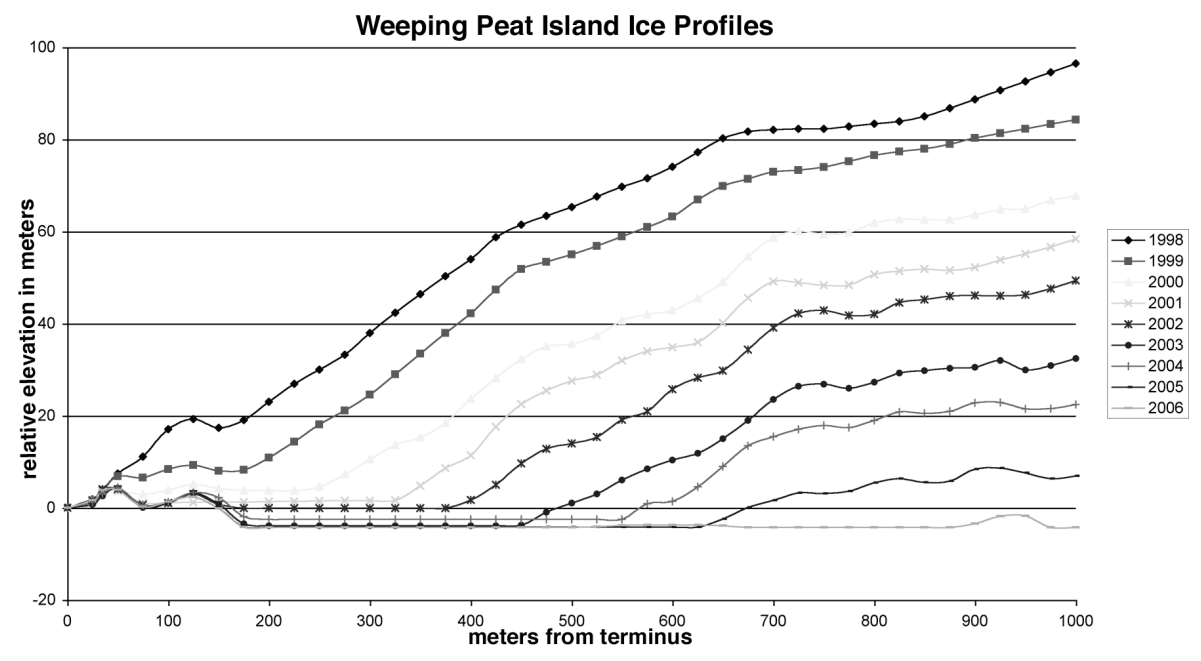

TCD

8, 2403-2424, 2014

Surface depressions (Lacunas) on Bering

Glacier, Alaska

P. J. Fleisher

Title Page

Abstract

Introduction

Conclusions

References

Tables

Figures

14

$>1$

4

Fig. 7. Annual ice surface profiles 1998-2006 from Weeping Peat Island survey station indicate a general downwasting rate of 10 myear $^{-1}$ (from Fleisher et al., 2010).

Back

Close

Full Screen / Esc

Printer-friendly Version

Interactive Discussion 